\title{
Cultural Intelligence And Global Business Competencies: A Framework For Organizational Effectiveness In The Global Marketplace
}

Carole Ann Creque, University of Mary Washington, USA Doreen J. Gooden, Florida International University, USA

\begin{abstract}
This paper proposes that cultural intelligence and global business competencies are vital to organizations as they seek to achieve success in the global marketplace. Adler (2001) suggests that because of the diversity of the global workforce cultural barriers may exist resulting in misunderstanding and thus inefficient interactions. Organizations will, therefore, have to understand the cultural foundation of the environment within which they operate in order to achieve organizational success.
\end{abstract}

Keywords: Cultural Intelligence; Global Business Competencies; Organizational Effectiveness

\section{INTRODUCTION}

lobalization is transforming the way business is conducted worldwide. Economies and business systems are now entwined with each other; new market-based economies are developing in former communist countries and trade barriers are no longer an obstacle to international trade and foreign direct investment. Success in this new world economy requires organizations to attract employees who have an understanding of culture and cultural diversity and possess the necessary skills and abilities to interact with and create relationships with people from other countries.

Triandis (2006) posits that the global environment promotes partner relationships between countries that are culturally different and suggests that cultural intelligence is needed in order to develop a good working relationship and successful interaction between partners. According to Thomas (2006) an individual who is knowledgeable about his own culture and learns about the culture of others will have a greater understanding of his own behavior and the behavior of others. Lane, Distefano \& Meznevski (2000) state that an individual who understands the heart of a culture will be able to visualize himself/herself in that new cultural environment.

\section{CULTURAL INTELLIGENCE}

Cultural intelligence (CQ) is a fairly new concept which refers to an individual's ability to adapt to and function effectively in culturally diverse situations. Lee and Sukoco (2010) refer to cultural intelligence as the "ability that an expatriate has to adapt across cultures" (p. 963). Brislin et al. (2006) conclude that cultural intelligence is "a set of skills, from basic to advanced, that allow an individual to become effective at eventually transferring social skills from one cultural context to another" (p.53) Thus, CQ is a type of intelligence that helps an individual cope with the variability of cultural diversity and also helps them to function within that setting.

Thomas et al. (2008) in their review of cultural intelligence summarized the work done in this area. This is presented in Table 1 below. 
Table 1 Definitions and applications of cultural intelligence

\begin{tabular}{|c|c|c|c|}
\hline Source & $\begin{array}{c}\text { Definition of cultural } \\
\text { intelligence }\end{array}$ & Constituent Elements & Outcomes/applications \\
\hline $\begin{array}{l}\text { Earley, 2002; Earley \& } \\
\text { Ang, } 2003\end{array}$ & $\begin{array}{l}\text { '... a person's capability to } \\
\text { adapt effectively to new } \\
\text { cultural contexts.' }\end{array}$ & $\begin{array}{l}\text { (Cognitive Including } \\
\text { metacognitive) } \\
\text { Motivational } \\
\text { Behavioral }\end{array}$ & $\begin{array}{l}\text { Global assignment success } \\
\text { Diversity assignments } \\
\text { Training methods }\end{array}$ \\
\hline Thomas \& Inkson, 2003 & $\begin{array}{l}\text { '... involves understanding } \\
\text { the fundamentals of } \\
\text { intercultural interaction, } \\
\text { developing a mindful } \\
\text { approach to intercultural } \\
\text { interactions, and finally } \\
\text { building adaptive skills and a } \\
\text { repertoire of behavior so that } \\
\text { one is effective in different } \\
\text { intercultural situations.' }\end{array}$ & $\begin{array}{l}\text { Knowledge } \\
\text { Mindfulness } \\
\text { Behavioral Skills }\end{array}$ & $\begin{array}{l}\text { Cross-cultural decision } \\
\text { making } \\
\text { Cross-cultural } \\
\text { communication } \\
\text { Cross cultural leadership; } \\
\text { Multicultural teams } \\
\text { International careers }\end{array}$ \\
\hline $\begin{array}{l}\text { Earley \& Mosakowski, } \\
2004\end{array}$ & $\begin{array}{l}\text { '. . . a seemingly natural } \\
\text { ability to interpret someone's } \\
\text { unfamiliar ambiguous } \\
\text { gestures in just the way that } \\
\text { person's compatriots and } \\
\text { motivational } \\
\text { colleagues would, even to } \\
\text { mirror them.' }\end{array}$ & $\begin{array}{l}\text { Cognitive } \\
\text { Physical } \\
\text { Emotional/Behavior }\end{array}$ & $\begin{array}{l}\text { Appropriate behavior in new } \\
\text { cultures }\end{array}$ \\
\hline Earley \& Peterson, 2004 & $\begin{array}{l}\text { '... reflects a person's } \\
\text { capability to gather, interpret, } \\
\text { and act upon these radically } \\
\text { different cues to function } \\
\text { effectively across cultural } \\
\text { settings or in a multicultural } \\
\text { situation.' }\end{array}$ & $\begin{array}{l}\text { Metacognitive/Cognitive } \\
\text { (e.g., learning strategies } \\
\text { and cultural sense } \\
\text { making) } \\
\text { Motivation (e.g., } \\
\text { cultural empathy } \\
\text { and self-efficacy) } \\
\text { Behavior (e.g., } \\
\text { acceptable behavior } \\
\text { in culture and mimicry) }\end{array}$ & $\begin{array}{l}\text { Intercultural training } \\
\text { Multinational teams }\end{array}$ \\
\hline Earley, Ang \& Tan, 2006 & $\begin{array}{l}\text { '... a person's capability for } \\
\text { successful adaptation to new } \\
\text { cultural settings, that is for } \\
\text { unfamiliar settings } \\
\text { attributable to cultural } \\
\text { context.' }\end{array}$ & $\begin{array}{l}\text { Cultural strategic thinking } \\
\text { Motivation } \\
\text { Behavior }\end{array}$ & $\begin{array}{l}\text { Diversity assignments } \\
\text { Global work assignments } \\
\text { Global teams } \\
\text { Global leadership }\end{array}$ \\
\hline Thomas, 2006 & $\begin{array}{l}\text { '. . . the ability to interact } \\
\text { effectively with people who } \\
\text { are culturally different.' }\end{array}$ & $\begin{array}{l}\text { Knowledge } \\
\text { Mindfulness } \\
\text { Behavior } \\
\end{array}$ & $\begin{array}{l}\text { Development } \\
\text { Assessment }\end{array}$ \\
\hline Ang et al., 2007 & $\begin{array}{l}\text { '. . an individual's capability } \\
\text { to function and manage } \\
\text { effectively in culturally } \\
\text { diverse settings.' }\end{array}$ & $\begin{array}{l}\text { Cognition } \\
\text { Metacognition } \\
\text { Motivation } \\
\text { Behavior }\end{array}$ & $\begin{array}{l}\text { Cultural judgment and } \\
\text { decision making Cultural } \\
\text { adaptation } \\
\text { and performance }\end{array}$ \\
\hline Thomas et al., 2008 & $\begin{array}{l}\text { '. . a system of interacting } \\
\text { knowledge and skills, linked } \\
\text { by cultural metacognition, } \\
\text { that allows people to adapt to, } \\
\text { select, and shape the cultural } \\
\text { aspects of their environment.' }\end{array}$ & $\begin{array}{l}\text { Cultural Knowledge Cross- } \\
\text { Cultural Skills Cultural } \\
\text { Metacognition }\end{array}$ & $\begin{array}{l}\text { Effective intercultural } \\
\text { interactions (personal } \\
\text { adjustment, interpersonal } \\
\text { relationship development, } \\
\text { task performance) }\end{array}$ \\
\hline
\end{tabular}

Source: Thomas et al., 2008 p. 126

We propose the following framework to discuss the importance of cultural intelligence and global business competencies to organizations as they strive for success in their global operations. 


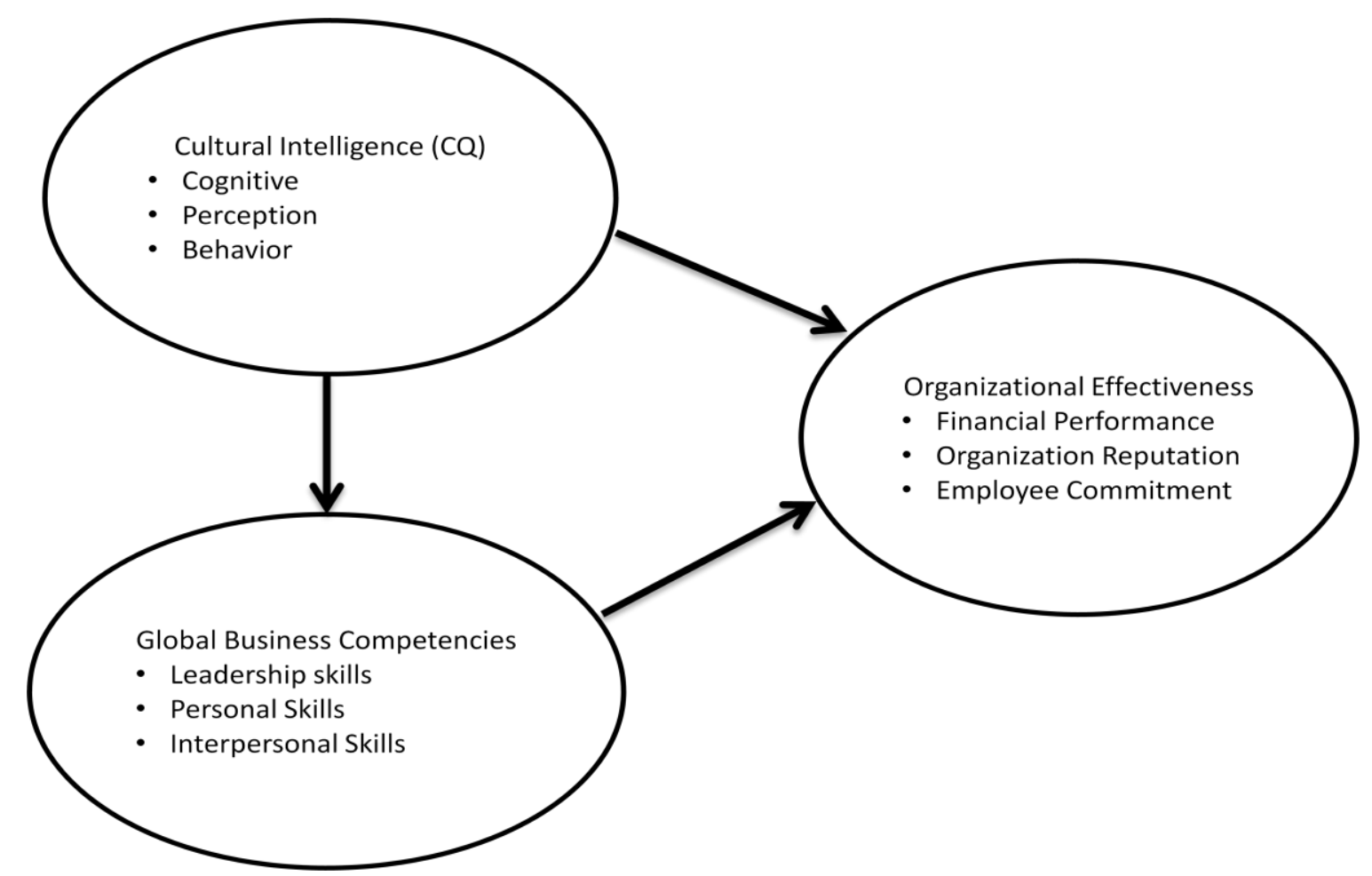

Figure 1: Cultural Intelligence and Global Business Competencies: Framework for Organizational Effectiveness

We define cultural intelligence as an individual's cognition or knowledge that influences his perception to a cultural environment or state and which leads to how he behaves in that environment. Cognition relates to the individual's knowledge and understanding of beliefs and customs of a particular culture. It also includes knowledge about the language and knowledge of the interaction process. This is important as the individual seeks to have a better understanding of others and himself, which is vital for cross-cultural adaptation. According to Thomas et al. (2008), cultural knowledge, in addition to referring to knowledge about cultures, social interactions and personal history, also includes knowledge of the impact of culture on "one's own nature or nature of another". Lane et al. (2000) posit that the content knowledge of cultures will enable the individual to mentally adapt in a new cultural environment.

Lee and Sukco (2010) found that expatriates with a high level of cultural intelligence are likely to have a high level of cultural adjustment - those with less cultural intelligence tend to have a low level of cultural adjustment. They also found that although an expatriate might have more international experience, if his cultural intelligence is low, then he would have a low level of cultural adjustment. Thus, they confirmed that the highest level of cultural effectiveness is reached, when expatriates have a high level of cultural intelligence and more international experience.

Earley (2002) suggests that knowledge alone will not lead to an individual being culturally adaptive. This is so, because self-selection criterion and ethnocentrism can negatively impact an individual's ability to be adaptive. Triandis (2006) argued that an individual who is exposed to only one culture will believe that the norms and beliefs in that culture should be the same for other cultures and, therefore, will not want to adapt when required to do so. Therefore, in addition to having the knowledge, the individual would need to have a change in perception and behavior to be truly adaptive.

Thus, the extent to which there is cognition about a cultural environment, and change in perception, then that could influence the action taken by an individual. If the individual does not possess the knowledge, self- 
efficacy, then that can hamper his action or behavioral change. Gregory et al. (2009) examined IT offshore project members with diverse socio-cultural background and found that an understanding of the other person's behavior is needed for effective interaction.

Research suggests that behavior modification training is necessary in order for an individual to be culturally intelligent. If there is training, then that increases the probability of desirable behavior and decreases the probability of undesirable behavior.

It was also found that people who are culturally intelligent are more flexible and more adaptive to different organizational environments. Thus, it could be argued that an individual's behavior should be flexible enough to respond appropriately to the different cross-cultural situations.

Brislin et al. (2006) suggest ways to prepare individual to interact with other cultures and propose the following four-step procedure for cultural intelligence development.

1. Consider behaviors in which people will likely engage in during their overseas assignment.

2. Introduce reasons for these behaviors as seen by people in the other culture.

3. Consider the emotional implications and emotional associations that accompany the behavior.

4. Now that understanding has improved, use the new knowledge as a jumping off point for learning about other behaviors and broader concepts that will increase cultural intelligence.

Thomas (2006) contends that mindfulness is a metacognitive strategy that links knowledge and behavior. Therefore, it could be concluded that the process of cultural intelligence starts with how a person obtains, converts and processes information, and how they discern, express, critique, rationalize, and imagine things. (Earley \& Ang, 2003; Ang et al., 2004 \& Thomas, 2006).

\section{GLOBAL BUSINESS COMPETENCIES (GBC)}

Miller (2001) argues that knowledge and functional competence are the starting point for the global competency equation. Tan and Chua (2003) postulate that cultural competencies include knowledge, skills, abilities and personal attributes. These competencies give the company its competitive advantage and are often ingrained in the company's culture and practices. Thus, an individual with these attributes will need to use them effectively in order to work successfully with individuals from different cultural background (Johnson et al. 2006). Knight and Kim (2009) argued that international business competencies are the firms' capabilities which allow them to effectively conduct international business and which has a positive effect on firm performance.

De la Garcia Carranza \& Egri (2010) posit that managerial cultural intelligence which can be viewed as human capital resource can have a positive impact on the firm's performance. They also argued that culturally intelligent managers are in a position to establish effective business relationships that would enhance international organizational performance.

LaFromboise et al. as reported by Johnson et al. (2006) suggest that for an individual to be culturally competent, he needs to:

1. Possess a strong personality

2. Have knowledge of and facility with the beliefs and values of the culture

3. Display sensitivity to the affective processes of the culture

4. Communicate clearly in the language of the given cultural group

5. Perform specially sanctioned behavior

6. Maintain active social relations within the cultural group

7. Negotiate the institutional structures of that culture

Dainty (2008) advocates that personal and interpersonal competencies are often seen as the potential stumbling blocks for success in the global environment. Inquisitiveness/curiosity and global mind-set have been 
identified as personal competencies. Wilson (1998) found that inquisitiveness was one of the most important determinants of expatriate success. Earley and Ang (2003) found that the more interest the individual has, the more motivated he will be in exploring and understanding the cultural nuances of the country. If an individual lacks interest, he will not be motivated and become disinterested in exploration and thus, less likely to be adaptable. Global mind-set according to Rhinesmith (1992) is "the predisposition to see the world in a particular way, set boundaries, question the rationale behind the things that are happening behind us and establish guidelines to show how we should behave" (p.63). Individuals with a global-mindset will view the world in an objective way and will more readily recognize that there are differences in each culture and, therefore, are more willing to be adaptive to these differences.

Alon and Higgins (2005) mentioned that leadership behaviors are moderated by cultural intelligence. A company that has leaders who are culturally intelligent will have individuals who are highly motivated and possess the necessary skills and abilities to develop cross-cultural interpersonal relationships. They are able to adapt to different cultural situations and, thus, are able to influence the behavior of their followers to perform successfully in globally diverse environments.

\section{ORGANIZATIONAL EFFECTIVENESS}

Drawing on de la Garza Carranza and Egri's work (2010), we propose that organizational effectiveness can be measured by examining the firm's financial performance, corporate reputation and employee commitment. Knight and Kim (2009) found that international business competencies, an intangible firm resource, positively impacts on firm performance. de la Garza and Egri (2010) found that cultural intelligence was positively related to corporate reputation and employee commitment but not for financial performance. Waclawski (2002) found that organizations having a flexible culture performed higher than those with less flexible systems and also found that there was a significant relationship between perceived cultural flexibility and financial performance. Knight and Kim (2009) suggest that international companies should develop competencies that are unique and inimitable in order to maximize their international performance.

\section{CONCLUSION}

In this paper, we proposed that cultural intelligence and business competencies are important factors for companies as they seek success in their international operations. We advocate that firms that are culturally intelligent will seek to have leaders who have global business competencies. Cultural intelligence recognizes that there are differences within each culture and that in order to be successful, organizations need to adapt to these cultural differences. Having cultural intelligent leaders with the necessary leadership skills, coupled with personal and interpersonal skills will enhance the firm's ability to succeed in the global marketplace.

This conceptual framework, can add to the growing body of knowledge of research on cultural intelligence. Cross-cultural research could be done to determine differences or similarities between developed and developing countries. Research can also be done to determine antecedents and moderating influences of factors on the relationship between cultural intelligence, global business competencies and organizational effectiveness.

\section{AUTHOR INFORMATION}

Dr. Carole Ann Creque is Assistant Professor of Marketing at the College of Business, University of Mary Washington, Virginia, USA. Her research interests are international marketing and cross-cultural management. Email: ccreque@umw.edu

Dr. Doreen J. Gooden is Lecturer/Instructor of Management and International Business at the College of Business, Florida International University, USA. Her research interests are cross-cultural management, corporate governance and foreign direct investments. E-mail: goodend@fiu.edu 


\section{REFERENCES}

1. Adler, N.J. (2002). International Dimensions of Organizational Behavior. (4 ${ }^{\text {th }}$ ed.), Cincinnati, OH: Southwestern College.

2. $\quad$ Adler, I. (2001). Culture Shock, Business Mexico. Vol. 11(5), p.21.

3. Alon, I. \& Higgins, J. (2005) Global leadership success through emotional and cultural intelligences, Business Horizons Vol. 48, p. 501-512.

4. Ang, S., \& Inkpen, A.C. (2008). Cultural Intelligence and Offshore Outsourcing Success: A Framework of Firm-Level Intercultural Capability, Decision Sciences, Vol. 39, p. 337-358.

5. Ang, S., Van Dyne, L., Koh, C., Ng, K.Y. (2004). The Measurement of Cultural Intelligence, Annual Meeting of the Academy of Management, New Orleans.

6. Ang, S., Van Dyne, L., \& Koh, C (2006). Personality Correlates of the Four-Factor Model of Cultural Intelligence, Group \& Organization Management, Vol. 31 (1), p. 100 - 124.

7. Brislin, R., Worthley, R., \& MacNab, B. (2006). Group \& Organization Management, Vol. 31(1), p. 40-55.

8. Dainty, P. (2008). Leading and Managing in a Global Environment: Developing Executive Competencies for the World Stage. MBS Working Paper Series. http://works. Beprrress.om/paul_dainty/2.

9. De la Garcia Carranza, M. T., \& Egri, C. P. (2010). Managerial Cultural Intelligence and Small Business in Canada. Management Review, 21(3), p. 353-371.

10. Earley, P. C. (2002). Redefining Interactions Across Cultures and Organizations: Moving Forward with Cultural Intelligence. In B.M. Shaw and R.M. Kramer (Eds) Research in Organizational Behavior Vol. 24, p. 271-299.

11. Earley, P.C. \& Ang, S. (2003). Cultural Intelligence: Individual Interactions Across Cultures. Stanford Business Books, Stanford, CA.

12. Gregory, R, Prifling, M., Beck, R. (2009). The role of cultural intelligence for the emergence of negotiated culture of IT Offshore-outsourcing projects, Information Technology and People Vol. 22 (3), p. 223-224.

13. Johnson, J., Lenartowicz, T., and Apud, S. (2006). Cross-cultural competence in international business: toward a definition and a model. Journal of International Business Studies, Vol. 37, p. 525-543

14. Knight, G., \& Kim, D. (2009). International business competence and the contemporary firm. Journal of International Business Studies, Vol. 40 (2), p. 255-273.

15. Lane, H. W., Distefano, J. J., \& Meznevski, M. L. (2000) International Management Behavior: Text, Readings \& Cases, Maiden, MA: Blackwell.

16. Lee, L.-Y. \& Sukco, B. M. (2010). The effects of Cultural Intelligence on Expatriate Performance: The moderating effects of international experience. The International Journal of Human Resource

Management, Vol. 21 (7), p. 963-981.

17. Miller, P. (2001). Competency Based Education and Training, Journal of Workplace Learning, Vol. 13 (5/6), p. 261.

18. Rhinesmith, S. H. T. (1992). Global Mindset for Global Managers, American Society for Training \& Development, Vol. 46 (10), p.63

19. Tan, J. S. \& Chua, R. Y. J. (2003).Training and Developing Cultural Intelligence, in P. C. Earley and S. Ang (eds.), Cultural Intelligence: Individual Interactions Across Cultures, Stanford Business Books:

Stanford CA. p. 258-303.

20. Thomas, D.C. (2006). Domain and Development of Cultural Intelligence: The Importance of Mindfulness. Group \& Organization Management. Vol. 319 (1), p. 78-99.

21. Thomas, D.C., Elron, E., Stahl, G., Ekelund, B. Z., Ravlin, E. C., Cerdin, J.-L., et al., (2008) Cultural Intelligence: Domain and Assessment. International Journal of Cross Cultural Management Sage: Vol. 82, p. 123-143.

22. Triandis, H.C. (2005). Cultural intelligence in organizations. Group \& Organization Management, Vol $37(1)$, p. $20-26$.

23. Triandis, H.C. (2006). Cultural Intelligence in Organizations. Group \& Organization Management, Vol. 31(1), p. 20-26

24. Waclawski, J. (2002). Large-scale Organizational Change and Performance: An Empirical Examination. Human Resource Development Quarterly, Vol. 13 (3), p. 289.

25. Wilson-Smith, A. (1998). Goosing the Globe, Maclean's, Vol. 111(13), p. 18-20. 